\title{
The urinary excretion of purine derivatives in sheep is not influenced by long term treatment with vasopressin*
}

\section{Š. Faix ${ }^{1}$, L. Leng ${ }^{1}$, J.J. Pająk ${ }^{2}$, M. Czauderna ${ }^{2}$, Z. Faixováa ${ }^{3}$, K. Boldižárová ${ }^{1}$ and J. Kowalczyk ${ }^{2}$}

\author{
${ }^{1}$ Institute of Animal Physiology, Slovak Academy of Sciences \\ Šoltésovej 4, 04001 Košice, Slovak Republic \\ ${ }^{2}$ The Kielanowski Institute of Animal Physiology and Nutrition, \\ Polish Academy of Sciences \\ 05-110 Jabłonna, Poland \\ ${ }^{3}$ Department of Pathological Physiology, University of Veterinary Medicine \\ Komenského 73, Košice, Slovak Republic
}

(Received 5 July 2002; revised version 24 March 2003; accepted 15 July 2003)

\begin{abstract}
This study examines the influence of vasopressin (1-desamino-8-D-arginine vasopressin (dDAVP)) on the urinary excretion of purine derivatives in sheep. Subcutaneous injections of $12.5 \mu \mathrm{g}$ of dDAVP given twice daily started 10 days before the measurements of renal functions. The urinary excretion of total purine derivatives was significantly lower in the dDAVP group ( $1.43 \pm 0.08$ vs $2.18 \pm 0.18$ $\left.\mu \mathrm{mol} \cdot \mathrm{min}^{-1}, \mathrm{P}<0.01\right)$. Similar results were obtained for excretion of allantoin $(0.90 \pm 0.07 \mathrm{vs}$ $\left.1.44 \pm 0.10 \mu \mathrm{mol} \cdot \mathrm{min}^{-1}, \mathrm{P}<0.001\right)$, uric acid $\left(0.30 \pm 0.02\right.$ vs $\left.0.45 \pm 0.05 \mu \mathrm{mol} \cdot \mathrm{min}^{-1}, \mathrm{P}<0.05\right)$ and xanthine $\left(0.015 \pm 0.002 \mathrm{vs} 0.008 \pm 0.002 \mu \mathrm{mol} \cdot \mathrm{min}^{-1}, \mathrm{P}<0.05\right)$. The urinary excretion of hypoxanthine was unaffected by dDAVP administrations $\left(0.22 \pm 0.01 \mathrm{vs} 0.28 \pm 0.03 \mu \mathrm{mol} \cdot \mathrm{min}^{-1}\right.$, NS). The clearance protocol showed a decreased urine flow rate $\left(1.40 \pm 0.12\right.$ vs $\left.3.58 \pm 0.44 \mathrm{ml} \cdot \mathrm{min}^{-1}, \mathrm{P}<0.001\right)$ without changes in glomerular filtration rate due to dDAVP. The urine urea concentration was significantly higher in the dDAVP group $\left(18.71 \pm 1.49\right.$ vs $\left.39.81 \pm 4.90 \mathrm{mmol} \cdot \mathrm{l}^{-1}, \mathrm{P}<0.01\right)$. We conclude that vasopressin did not affect excretion of purine derivatives by the kidneys of sheep. The lower amount of total purine derivative excretion after treatment with vasopressin is a reflection of the urinary flow rate and water reabsorption.
\end{abstract}

KEY WORDS: purine derivatives, allantoin, vasopressin, kidney, water reabsorption, sheep

\footnotetext{
* Supported by the Grant Agency for Science,VEGA, Slovak Republic, Grant No. 2/7028/20
} 


\section{INTRODUCTION}

In ruminants dietary nucleic acids are extensively degraded in the rumen, and duodenal purines appear to originate predominantly from rumen microorganisms (McAllan and Smith, 1973). Nucleic acid bases, nucleosides and nucleotides present in duodenal digesta are degraded during passage through the intestinal mucosa and generally absorbed as nucleosides (McAllan, 1982). The metabolism of purine bases into allantoin consists of a series of reactions involving hypoxanthine, xanthine, uric acid and allantoin, all of which are excreted in urine, with allantoin constituting the greatest proportion. A number studies (Topps and Elliot, 1965; Antoniewicz et al., 1980; Verbič et al., 1990) have demonstrated that measurements of urinary excretion of allantoin, hypoxanthine, uric acid and xanthine could potentially be used as the basis for a noninvasive index of microbial protein supply in sheep and dairy cows. However, not all purine metabolites excreted in ruminant urine originate from metabolism of absorbed purines. During tissue nucleic acid turnover a proportion of purine bases are not salvaged and reutilized but enter catabolic pathways, constituting an endogenous loss. Allantoin, uric acid, xanthine and hypoxanthine can all be recovered from the urine of ruminants in varying proportions depending on the nutrition of the animal. More recent work has confirmed a close correlation between the intake of digestible dry matter or organic matter and urinary allantoin excretion in cattle (Vercoe, 1976), sheep (Antoniewicz et al., 1981) and goats (Lindberg, 1985). Lindberg (1989) showed that the endogenous urinary excretion of purine derivatives in a young growing ruminant was only marginally affected by large variations in protein supply, and also by the level of intake of milk. We demonstrated in our previous paper (Faix et al., 1988) that the kidneys of sheep regulate urea excretion (the main protein metabolite in ruminants) dependent upon protein and energy intake. During a low protein diet, renal excretion of urea is reduced by a decreased filtered load of urea and an enhanced capacity for urea reabsorption from tubules and the renal pelvis (Cirio and Boivin, 1990). The effect of highly-concentrated urine induced by vasopressin administration in sheep which are fed a high protein diet does not result in a rise of glomerular filtration rate, but this is a possible response to recycling of urea nitrogen through the digestive tract (Boldižárová et al., 1999).

The aim of this study was to investigate the effect of the formation of highlyconcentrated urine induced by a vasopressin administration on the urinary excretion of purine derivatives in sheep.

\section{MATERIAL AND METHODS}

\section{Animals and diets}

The experiments were carried out on twelve female sheep of Polish Lowland breed weighing from 40 to $45 \mathrm{~kg}$. The sheep were housed individually and had free access to water and minerals. The animals were fed a diet for at least 3 weeks 
before the measurement of kidney functions. The total daily ration for each sheep consisted of $40 \mathrm{~g}$ of rapeseed oilmeal, $400 \mathrm{~g}$ of barley and $800 \mathrm{~g}$ of hay, containing $1103 \mathrm{~g}$ of dry matter and $148.3 \mathrm{~g}$ of crude protein.

\section{Experimental design}

The animals were divided into two groups, six control sheep and six sheep treated with vasopressin analogue. The experimental group was given subcutaneous injections of $12.5 \mu \mathrm{g}$ 1-desamino-8-D-arginine vasopressin (dDAVP, Adiuretin-SD, Ferring-Léčiva a.s., Prague), a synthetic analogue of vasopressin with prolonged effects, twice daily in $125 \mu \mathrm{l}$ of glycerol. The treatment began ten days before the measurements of kidney functions. The control group received injections of glycerol for the same period only. The renal functions were measured by a standard clearance technique on conscious sheep fixed in cages. The right jugular vein was cannulated with a polyethylene capillary and used for the infusion of pyrogen-free inulin (Sigma) dissolved in sterile $0.15 \mathrm{~mol}$ $\mathrm{NaCl}$. The priming dose of inulin solution ( $1 \mathrm{~g}$ in $50 \mathrm{ml}$ ) was injected through a jugular cannula and then a continuous infusion of inulin $\left(6.6 \mathrm{mg} \cdot \mathrm{ml}^{-1} \cdot \mathrm{min}^{-1}\right)$ was initiated.

\section{Sample collection}

Samples of urine were quantitatively collected into calibrated glass cylinders through a Foley catheter placed in the urinary bladder. Three collection periods were set up for every animal. The first urine collection period began $90 \mathrm{~min}$ after the start of inulin infusion to allow its equilibrium in the extracellular space. Each collection period lasted $30 \mathrm{~min}$. Blood was sampled from the left jugular vein into heparinized tubes at the mid-point of every urine collection period.

\section{Analytical methods}

Inulin was measured in urine and blood plasma samples using the Heyrovsky method (1957) and urea using the Conway method (1962). Separation and quantification of purine derivatives (allantoin, uric acid, xanthine and hypoxanthine) in urine were achieved using the modified HPLC method using two Nova-Pak $\mathrm{C}_{18}$ columns (Czauderna and Kowalczyk, 2000). The osmolality of plasma and urine were determined cryoscopically on a Knauer osmometer.

\section{Statistical analysis}

The statistical significance of the differences between control values and values obtained from the dDAVP treated group was assessed using Student's t-test. The results are given as the arithmetic means and standard error of means (SEM). 


\section{RESULTS AND DISCUSSION}

The study of the urinary excretion of purine derivatives by sheep (Table 1) shows that urine concentrations of allantoin, uric acid and hypoxanthine were significantly higher after vasopressin administration. The urine concentration of xanthine was also higher, but without significant differences compared with control sheep. Higher concentrations of purine derivatives are the result of more concentrated urine, which is documented by higher urine osmolality $(241.30 \pm 36.85$ vs $\left.411.40 \pm 26.41 \mathrm{mosm} \cdot \mathrm{kg}^{-1} \mathrm{H}_{2} \mathrm{O} ; \mathrm{P}<0.01\right)$.

TABLE 1

The effect of vasopressin analogue (dDAVP) administration on the urine concentration and urine excretion of purine metabolites in sheep

\begin{tabular}{lccl}
\hline Indices & Control group & dDAVP group & $\mathrm{P}<$ \\
\hline Allantoin, $\mu \mathrm{mol} \cdot \mathrm{l}^{-1}$ & $420 \pm 60$ & $690 \pm 80$ & 0.05 \\
Amount of allantoin excreted, $\mu \mathrm{mol} \cdot \mathrm{min}^{-1}$ & $1.44 \pm 0.10$ & $0.90 \pm 0.07$ & 0.001 \\
Uric acid, $\mu \mathrm{mol} \cdot \mathrm{l}^{-1}$ & $140 \pm 30$ & $230 \pm 30$ & 0.05 \\
Amount of uric acid excreted, $\mu \mathrm{mol} \cdot \mathrm{min}^{-1}$ & $0.45 \pm 0.05$ & $0.30 \pm 0.02$ & 0.05 \\
Xanthine, $\mu \mathrm{mol} \cdot \mathrm{l}^{-1}$ & $4.3 \pm 1.3$ & $5.8 \pm 1.1$ & $\mathrm{NS}$ \\
Amount of xanthine excreted, $\mu \mathrm{mol} \cdot \mathrm{min}^{-1}$ & $0.015 \pm 0.002$ & $0.008 \pm 0.002$ & 0.05 \\
Hypoxanthine, $\mu \mathrm{mol} \cdot \mathrm{l}^{-1}$ & $80 \pm 10$ & $170 \pm 20$ & 0.01 \\
Amount of hypoxanthine excreted, $\mu \mathrm{mol} \cdot \mathrm{min}^{-1}$ & $0.28 \pm 0.03$ & $0.22 \pm 0.01$ & $\mathrm{NS}$ \\
Total purine derivates, $\mu \mathrm{mol} \cdot \mathrm{l}^{-1}$ & $640 \pm 100$ & $1100 \pm 160$ & 0.05 \\
Amount of total purine derivatives excreted, $\mu \mathrm{mol} \cdot \mathrm{min}^{-1}$ & $2.18 \pm 0.18$ & $1.43 \pm 0.08$ & 0.01 \\
\hline
\end{tabular}

values are means \pm SEM, $n=6$ for each group

According to our results it is evident that not only intake and nutrient status have effects on the concentrations of purine derivatives in the urine, but a significant role is also played by urine volume and urinary flow rate. It would be interesting to find out the effect of a diet with high and low nitrogen and digestible energy contents on the excretion of purine derivatives, as our previous study (Faix et al., 1988) showed that different dietary nitrogen and digestible energy intakes have no effects on urine flow rate, but that glomerular filtration rate decreased when sheep were fed a low protein diet. Parasitkusol et al. (2002) demonstrated that glomerular filtration rate was an important factor affecting the amount of urinary allantoin recovered, and that incomplete recovery of plasma ${ }^{14} \mathrm{C}$ allantoin in the urine indicated losses of plasma ${ }^{14} \mathrm{C}$ allantoin via non-renal routes, which is supported by the presence of ${ }^{14} \mathrm{C}$ in saliva. Osuji et al. (1993) demonstrated the potential of purine derivative concentration in total urine as a predictor of intake and nutrient status in sheep. The experiments of Parasitkusol et al. (2002) with intravenously administered ${ }^{14} \mathrm{C}$ allantoin proved that the recovery of ${ }^{14} \mathrm{C}$ allantoin showed no relation to the level of feed intake. Likewise, the sampling period had no influence on the concentration of purine derivatives in urine, when urine was collected over three periods in the 
morning, at noon and in the evening (Nsahlai et al., 2000). Urinary and plasma purine derivatives in fed and fasted llamas were examined by Bakker et al. (1996). They showed that daily urinary excretion of purine derivatives decreased with feed intake and leveled on the last 3 days of fasting. Chen et al. (1992a) suggest that the changes in endogenous allantoin excretion may reflect remodeling of the metabolic state of the animal during periods when protein supply fluctuates. Chen et al. (1992b) also show that dry matter intake and body weight have an effect on purine derivatives excretion and microbial protein supply in sheep. Surra et al. (1997) concluded that the urinary excretion of purine derivatives is independent both of the supply of nucleic acids to the caecum and of the extent of hind gut fermentation, although it may be affected by variations in the flow of undigested fibre along the small intestine. The increase in microbial $\mathrm{N}$ flow at the duodenum may be provoked by higher levels of rumen $\mathrm{NH}_{3}$ concentration (Balcells et al., 1993).

Data in Table 2 shows that ten-day administration of vasopressin highly significantly reduced urinary flow rate $(\mathrm{P}<0.001)$ and fractional excretion of water $(\mathrm{P}<0.01)$, which is conditioned by the antidiuretic role of the arginine vasopressin (Wood et al., 1986). Plasma urea concentration $\left(\mathrm{P}_{\text {urea }}\right)$ and renal urea reabsorption $\left(\mathrm{Reab}_{\text {urea }}\right)$ showed higher values in the dDAVP group in comparison with the control group, but without significant differences compared with our previous paper, where these differences were significantly higher (Boldižárová et al., 1999). The explanation lies in the number of sheep which were used for statistical analysis, when in our previous experiments we used 11 sheep for each group and now 6 sheep for each group. Similar results were observed in the amount of urea excreted and fractional urea excretion, when we measured lower values in the dDAVP group compared with the control group, but without significant differences (NS). Significantly higher urine osmolality $(\mathrm{P}<0.01)$ is proof of the formation of highly-concentrated urine induced by exogenous administration of vasopressin. Vasopressin regulates urine osmolality by increasing cortical and medullary collecting duct luminal membrane permeability to water by activation of V2 receptors. Vasopressin contributes to

TABLE 2

The effect of vasopressin analogue (dDAVP) administration on the renal functions in sheep

\begin{tabular}{lrrl}
\hline Indices & Control group & dDAVP group & $\mathrm{P}<$ \\
\hline Urinary flow rate, $\mathrm{ml} \cdot \mathrm{min}^{-1}$ & $3.58 \pm 0.44$ & $1.40 \pm 0.12$ & 0.001 \\
Glomerular filtration rate, $\mathrm{ml} \cdot \mathrm{min}^{-1}$ & $55.30 \pm 5.99$ & $62.80 \pm 8.39$ & $\mathrm{NS}$ \\
Fractional excretion of water, $\%$ & $7.16 \pm 1.20$ & $2.43 \pm 0.27$ & 0.01 \\
Plasma urea concentration, $\mathrm{mmol} \cdot \mathrm{l}^{-1}$ & $5.88 \pm 0.70$ & $6.65 \pm 0.56$ & $\mathrm{NS}$ \\
Urine urea concentration, $\mathrm{mmol} \cdot \mathrm{l}^{-1}$ & $18.71 \pm 1.49$ & $39.81 \pm 4.90$ & 0.01 \\
Amount of urea excreted, $\mu \mathrm{mol} \cdot \mathrm{min}^{-1}$ & $62.69 \pm 4.56$ & $53.98 \pm 3.87$ & $\mathrm{NS}$ \\
Plasma osmolality, $\mathrm{mosm} \cdot \mathrm{kg}^{-1} \mathrm{H}_{2} \mathrm{O}$ & $302.10 \pm 0.99$ & $302.90 \pm 1.76$ & $\mathrm{NS}$ \\
Urine osmolality, $\mathrm{mosm} \cdot \mathrm{kg}^{-1} \mathrm{H}_{2} \mathrm{O}$ & $241.30 \pm 36.85$ & $411.40 \pm 26.41$ & 0.01 \\
Osmotic clearance, $\mathrm{ml} \cdot \mathrm{min}^{-1}$ & $2.58 \pm 0.20$ & $1.89 \pm 0.15$ & 0.05 \\
\hline
\end{tabular}

values are means \pm SEM, $n=6$ for each group 
further concentration of urine by increasing the medullary concentration gradient by activating a distinct urea transporter (Nielsen and Knepper, 1993). Vasopressin also induces a selective decrease in inner medullary blood flow without altering the cortical blood flow, which also contributes to the maximum concentrating ability of the kidney (Franchini and Cowley, 1996).

In conclusion, the results demonstrate that vasopressin has no direct effect on the urinary excretion of purine derivatives in sheep. The lower excretion of purine derivatives is a reflection of urinary flow rate and water reabsorption.

\section{REFERENCES}

Antoniewicz A.M., Heinemann W.W., Hanks E.M., 1980. The effect of changes in the intestinal flow of nucleic acids on allantoin excretion in the urine of sheep. J. Agr. Sci. 95, 395-400

Antoniewicz A.M., Heinemann W.W., Hanks E.M., 1981. Effect of level of feed intake and body mass on allantoin excretion and the allantoin to creatinine ratio in the urine of sheep. Rocz. Nauk. Zoot. 8, 49-65

Bakker M.L., Chen X.B., Kyle D.J., Ørskov E.R., Bourke D.A., 1996. Urinary and plasma purine derivatives in fed and fasted llamas (Lama glama and L. guanacoe). Comp. Biochem. Physiol. Pt. B. 113, 367-374

Balcells J., Guada J.A., Castrillo C., Gasa J., 1993. Rumen digestion and urinary excretion of purine derivates in response to urea supplementation of sodium-treated straw fed to sheep. Brit. J. Nutr. 69, 721-732

Bizub V., Leng L., 1997. The effect of the long-term administration of vasopressin on the development of the kidneys of growing lambs. Res. Vet. Sci. 62, 189-190

Boldižárová K., Faix Š., Leng L'., 1999. The renal response of sheep fed a high protein diet to treatment with vasopressin analogue. Acta Vet. Brno 68, 99-104

Chen X.B., Mathieson J., Hovell F.D.De B., Reeds P.J., 1990. Measurement of purine derivates in urine of ruminants using automated methods. J. Sci. Food Agr. 53, 23-33

Chen X.B., Chowdhury S.A., Hovell F.D.De B., Ørskov E.R., Kyle D.J., 1992a. Endogenous allantoin excretion in response to changes in protein supply in sheep. J. Nutr. 122, 2226-2232

Chen X.B., Chen Y.K., Franklin M.F., Ørskov E.R., Shand W.J., 1992b. The effect of feed intake and body weight on purine derivative excretion and microbial protein supply in sheep. J. Anim. Sci. 70, 1534-1542

Cirio A., Boivin R., 1990. Urea recycling from the renal pelvis in sheep: a study with $\left[{ }^{14} \mathrm{C}\right]$ urea. Amer. J. Physiol. 258, F1196-F1202

Conway E.J., 1962. Microdiffusion Analysis and Volumetric Error. Crosby, Lockwoood and Son, Ltd., London

Czauderna M., Kowalczyk J., 2000. Quantification of allantoin, uric acid, xanthine and hypoxanthine in ovine urine by high-performance liquid chromatography and photodiode array detection. J. Chromatogr. B. 7, 744, 129-138

Faix Š., Leng L., Szanyiová M., Várady J., Bod’a K., 1988. Effect of energy dietary intake on tubular urea reabsorption in sheep. Physiol. Bohemoslov. 37, 493-501 
Franchini K.G., Cowley A.W. Jr., 1996. Renal cortical and medullary blood flow responses during water restriction: role of vasopressin. Amer. J. Physiol. 270, R1257-R1264

Heyrovský A., 1957. A new way of determining inulin in plasma and urine (in Czech). Vnitřní lékařstvý, III, 2, 173-178

Leng L', Szanyiová M., Bod'a K., 1985. The renal response of sheep to a low dietary nitrogen intake. Physiol. Bohemoslov. 34, 147-159

Lindberg J.E., 1985. Urinary allantoin excretion and digestible organic matter intake in dairy goats. Swed. J. Agr. Res. 15, 31-37

Lindberg J.E., 1989. Nitrogen metabolism and urinary excretion of purines in goat kids. Brit. J. Nutr. 61, 309-321

McAllan A.B., 1982. The fate of nucleic acids in ruminants. Proc. Nutr. Soc. 41, 309-317

McAllan A.B., Smith R.H., 1973. Degradation of nucleic acids in the rumen. Brit. J. Nutr. 29, 331345

Nielsen S., Knepper M.A., 1993. Vasopressin activates collecting duct urea transporters and water channels by distinct physical processes. Amer. J. Physiol. 256, F204-F213

Nsahlai I.V., Osuji P.O., Umunna N.N., 2000. Effect of form and of quality of feed on the concentrations of purine derivates in urinary spot samples, daily microbial $\mathrm{N}$ supply and predictability of intake. Anim. Feed Sci. Tech. 85, 223-238

Osuji P.O., Nsahlai I.V., Khalili H., 1993. Intake prediction with urinary nitrogenous products. In: Proceedings of the 7th World Conference of Animal Production. Edmonton (Canada), pp. 40-41

Parasitkusol P., Ørskov E.R., Chen X.B., Hovell F.D., Kyle D.J., 2002. Variation between sheep in renal excretion of $\left[{ }^{14} \mathrm{C}\right]$ allantoin. Brit. J. Nutr. 87, 561-568

Surra J.C., Guada J.A., Balcells J., Castrillo C., 1997. Effects of post-ruminal fermentation on the faecal and urinary excretion of purines. Anim. Sci. 65, 383-390

Topps J.H., Elliot R.C., 1965. Relationsheep between concentrations of ruminal nucleic acids and excretion of purine derivates by sheep. Nature 205, 498-499

Verbič J., Chen X.B., MacLeod N.A., Ørskov E.R., 1990. Excretion of purine derivatives by ruminants. Effect of microbial nucleic acid infusion on purine derivative excretion by steers. J. Agr. Sci. $114,243-248$

Vercoe J.E., 1976. Urinary allantoin excretion and digestible dry-matter intake in cattle and buffalo. J. Agr. Sci. 86, 613-615

Wood L.L., Cheung C.Y., Power G.G., Brace R.A., 1986. Role of arginine vasopressin in fetal renal response to hypertonicity. Amer. J. Physiol. 251, F156-F163

\section{STRESZCZENIE}

Wydalanie pochodnych purynowych w moczu owiec nie zależy od długotrwałego podawania wazopresyny

Badano wpływ wazopresyny (1-desamino-8-D-arginina wazopresyna [dDAVP] na wydalanie pochodnych purynowych w moczu owiec. Na 10 dni przed pomiarem funkcji nerek dwa razy dziennie podawano podskórnie $12,5 \mathrm{mg}$ dDAVP.

Całkowite wydalanie pochodnych purynowych w moczu w grupie owiec otrzymujących dDAVP było $(\mathrm{P}<0,01)$ mniejsze niż u owiec kontrolnych $\left(1,43 \pm 0,08\right.$ vs $2,18 \pm 0,18 \mu \mathrm{mol} \cdot \mathrm{min}^{-1}$, odpowiednio). Podobnie wydalanie w moczu alantoiny $\left(0,90 \pm 0,07\right.$ vs $\left.1,44 \pm 0,10 \mu \mathrm{mol} \cdot \mathrm{min}^{-1}, \mathrm{P}<0,1\right)$, kwa- 
su moczowego $\left(0,30 \pm 0,02\right.$ vs $\left.0,45 \pm 0,05 \mu \mathrm{mol} \cdot \mathrm{min}^{-1}\right)$ i ksantyny $(0,008 \pm 0,002$ vs $0,015 \pm 0,002$ $\left.\mu \mathrm{mol} \cdot \mathrm{min}^{-1} ; \mathrm{P}<0,05\right)$ było $\mathrm{w}$ grupie otrzymującej wazopresynę mniejsze niż u owiec kontrolnych. Iniekcje dDAVP nie miały wpływu na wydalanie hipoksantyny w moczu $(0,22 \pm 0,01$ vs $0,28 \pm 0,03$ $\left.\mu \mathrm{mol} \cdot \mathrm{min}^{-1}\right)$.

Tempo przepływu moczu w grupie doświadczalnej było mniejsze w grupie doświadczalnej $(1,40$ $\pm 0,12$ vs $\left.358 \pm 0,44 \mu \mathrm{mol} \cdot \mathrm{min}^{-1} ; \mathrm{P}<0,001\right)$ niż w kontrolnej, bez zmian w filtracji kłębkowej, zależnych od dDAVP. Koncentracja mocznika w moczu była istotnie większa w grupie otrzymującej iniekcje dDAVP $\left(39,81 \pm 4,90\right.$ vs $\left.18,71 \pm 1,49 \mathrm{mmol} \cdot 1^{-1} ; \mathrm{P}<0,01\right)$ niż kontrolnej.

Stwierdzono, że wazopresyna nie ma wpływu na wydalanie pochodnych purynowych w moczu owiec. Mniejsze całkowite wydalanie pochodnych purynowych po iniekcji wazopresyny jest odbiciem tempa przepływu moczu i reabsorbcji wody. 